\title{
The contribution of magnetic resonance spectroscopy as biomarker in Alzheimer's disease
}

\author{
Pedro J. Modrego \\ Department of Neurology, Hospital Miguel Servet, Zaragoza, Spain \\ Correspondence: Pedro J. Modrego, MD. Address: Department of Neurology, Hospital Miguel Servet, Zaragoza 50009, \\ Spain. Email: med009626@saludalia.com. \\ Received: June 5, 2012 \\ DOI : $10.5430 / j b g c . v 3 n 1 p 66$ \\ Online Published: December 19, 2012 \\ Accepted: J une 27, 2012 \\ URL: http://dx.doi.org/10.5430/jbgc.v3n1p66
}

\section{Abstract}

The use of biomarkers is growing in the early detection of Alzheimer's disease (AD). Although some biomarkers such as medial temporal lobe volumetry, amyloid Positron Emision Tomography (PET), and A $\beta 42$ in CSF are being widely used, there is no clear consensus about the best biomarker to be used in each phase of the disease. Magnetic Resonance Spectroscopy (MRS) of the brain is less known as biomarker but has proven useful according to cross-sectional and longitudinal studies. This technique measures metabolite levels that reflect the degree of pathology in the brain. N-acetyl aspartate (NAA), a marker of neuronal density, decreases and Myo-inositol, a marker of glial proliferation, increases as the disease progresses. Decreased NAA levels have been detected in the prodromal phases of AD and even in presymptomatic stages in carriers of tau and amyloid protein mutations. Longitudinal studies have demonstrated good correlation between NAA levels and progression of AD, even in spite of treatment with cholinesterase inhibitors. From clinical trials we have learned that the current therapies have a modest effect on AD progression and that they do not have neuroprotective effects. This modest effect is reflected in the modest or null changes in metabolite levels in clinical trials using MRS as biomarker.

\section{Key words}

Magnetic resonance spectroscopy, Alzheimer's disease

\section{Introduction}

Given that Alzheimer's disease (AD) is a devastating and highly prevalent disorder in western countries, the use of biomarkers for early diagnosis is growing in the last decade. To date there are no sensitive enough and cost-efficient biomarkers to carry out in the general elderly population in the presymptomatic phases of the disease although this may change with the advances in this field. However the use of biomarkers has been recognized as useful in the condition that we call Mild Cognitive Impairment $(\mathrm{MCI})^{[1]}$, especially in the amnestic form, which reaches a prevalence of around $6 \%$ in the elderly population ${ }^{[2]}$.

Amnestic MCI is defined as an elderly-related memory impairment that does not fulfill the criteria of dementia and that does not interfere with daily living activities. Of course other cognitive inefficiencies may be present. By abnormal memory in this context we mean a score in memory tests of $1.5 \mathrm{SD}$ below that which is obtained in age and educationmatched controls ${ }^{[1]}$. The risk of conversion to dementia in MCI patients varies depending on conceptual definition and 
follow-up period, between the following percentages: $12 \%$ per year for 4 years in comparison to $1 \%-2 \%$ annual for controls ${ }^{[1]}, 40 \%$ across 2 years ${ }^{[3]}, 34 \%$ over 4.5 years ${ }^{[4]}, 53 \%$ over 3 years ${ }^{[5]}$, and $100 \%$ across $5-9.5$ years ${ }^{[6,7]}$.

In the newly published criteria of AD a panel of experts established that an early diagnosis of AD can be made in amnestic MCI when clinical criteria are met plus the presence of one or two biomarkers ${ }^{[8]}$. They considered two types of biomarkers: those of neuronal injury (hippocampal volumetry, CSF tau, rate of brain atrophy, FDG PET, and SPECT), and those of amyloid deposition (CSF A 342 and amyloid PET). A MCI syndrome is considered to be AD with high likelihood when both neuronal injury and amyloid deposition biomarkers are positive. When only one type of biomarker is positive then they consider an intermediate likelihood of being AD. Other neuroradiological techniques such as Diffusion MRI, perfusion MRI, and Magnetic Resonance Spectroscopy (MRS) are considered as less well validated biomarkers ${ }^{[8]}$.

In this review we are focusing on MRS as biomarker of early AD.

\section{Physical basis of MRS}

Proton Magnetic Resonance Spectroscopy (MRS) allows us to investigate biochemical abnormalities in living tissues. The most frequently used spectroscopy is the technique that originates from the Hydrogen nuclei (proton 1H-MRS). This technique is based on the differences in resonance obtained from the hydrogen nuclei depending on the surrounding atoms (chemical shift) when a magnetic field is applied. Currently the spectra may be acquired with univoxel (SV) or multivoxel techniques (MV) ${ }^{[9]}$. The Univoxel technique has the advantages of better spatial location, greater homogeneity, better water suppression, and quicker acquisition of the spectrum as compared to the MV technique. However, only one spectrum can be obtained per acquisition. Conversely, the multivoxel technique (MV) makes it possible to obtain multiple spectra per acquisition simultaneously and to assess a greater area of the brain; however the spectral resolution is smaller. To date the uni-voxel technique is still superior to the MV technique on the grounds of reproducibility ${ }^{[10,11]}$.

Voxels must be positioned away from sources of susceptibility artifacts (air, fat, necrotic areas, cerebrospinal fluid, metal, calcification, and bone). For diffuse processes, a $2 \mathrm{~cm} \times 2 \mathrm{~cm} \times 2 \mathrm{~cm}$ voxel is routinely used. For local lesions, the $\mathrm{SV}$ can be reduced in volume ${ }^{[9]}$.

The basic principle underlying single-voxel localization techniques is to use three mutually orthogonal slice selective pulses and design the pulse sequence to collect only the echo signal from the point (voxel) in space where all three slices intersect (see Figure 1). There are two modalities of spectral acquisition: PRESS or probe-p (point resolved spectroscopy) and STEAM (stimulated echo acquisition mode). The PRESS mode is used more frequently than STEAM mode because it increases the signal/noise ratio and is less sensitive to movement artifacts ${ }^{[12]}$. Each metabolite being assessed discloses a different frequency of hydrogen resonance and appears in a different site of the spectrum. The most frequently evaluated metabolites are $\mathrm{N}$-acetyl-aspartate as neuronal and axonal marker (NAA), myo-inositol (mI) as glial marker, choline (Ch) that reflects the cellular membrane turnover, creatine $(\mathrm{Cr})$ as marker of metabolism and internal reference value, and glutamate (Glx) as marker of metabolism of amino acids. The position of the metabolite signal is identified on the horizontal axis by its chemical shift, scaled in units referred to as parts per million (ppm). When all appropriate factors are considered, such as the number of protons and relaxation times a signal can be converted to a metabolite concentration by measuring the area under the curve. Given that water is the main component in living beings and its concentration is much higher than that of other metabolites, it is necessary to suppress the signal of resonance from the hydrogen of water. A plot showing peak amplitudes and frequencies is obtained. Each spectrum shows peaks corresponding to the different metabolite values: Myo-inositol (mI), 3.56 and $4.06 \mathrm{ppm}$; Choline compounds (Ch), $3.23 \mathrm{ppm}$; Creatine (Cr), 3.03 and 3.94 ppm; y N-acetil-aspartate (NAA), 2.02; 2.5 and 2.6 ppm; Glx-glutamine and glutamate, 2.1-2.55 ppm and 3.8 ppm (see figure 2). The ratios between metabolites and creatine are also of great value as they counteract the systematic errors of measurements. 


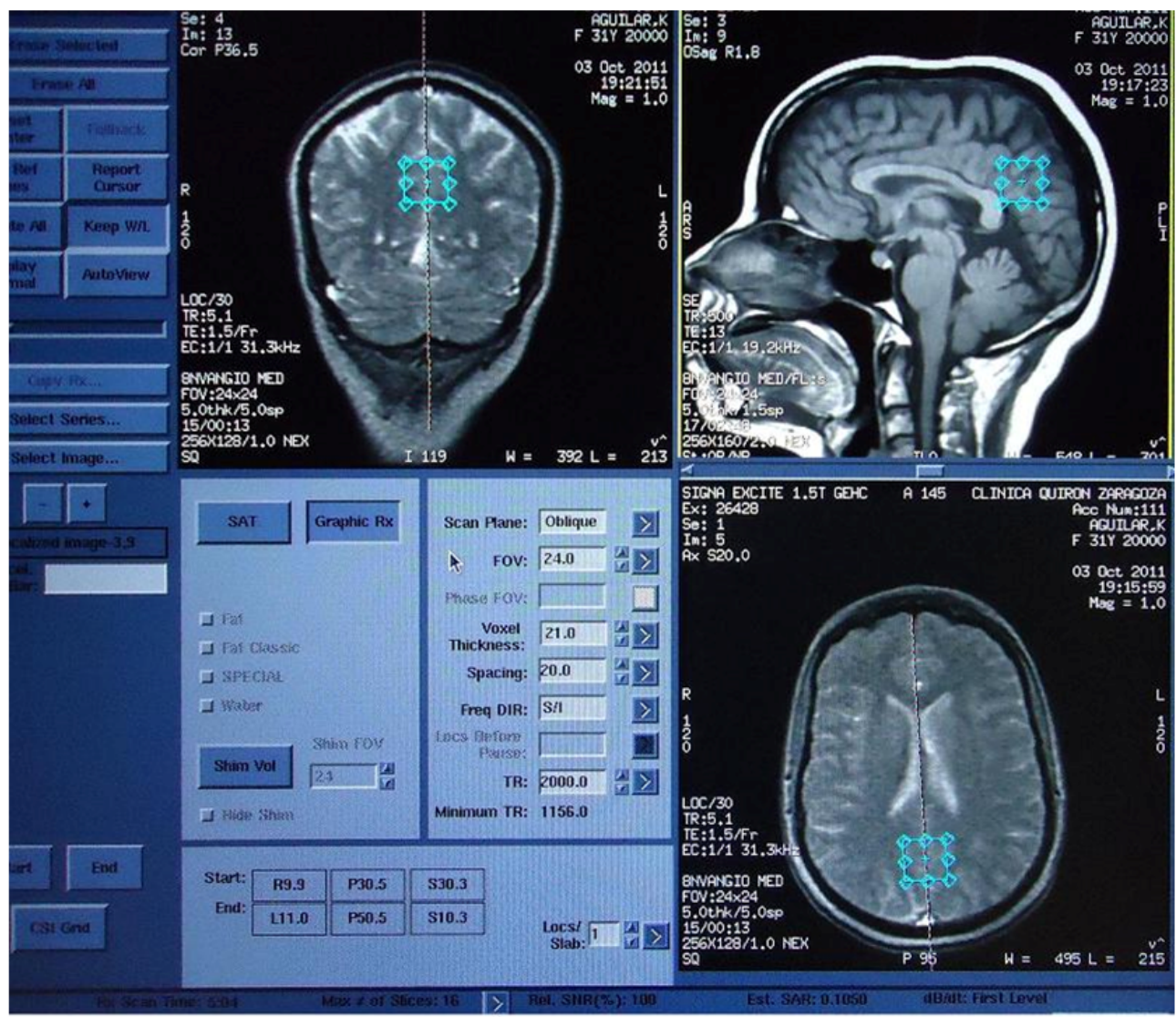

Figure 1. Positioning of a voxel in the bilateral posteromedial parietal cortex for study with frontal, sagittal and axial slices. The area explored includes the posterior cingulate gyrus and inferior precuneus.

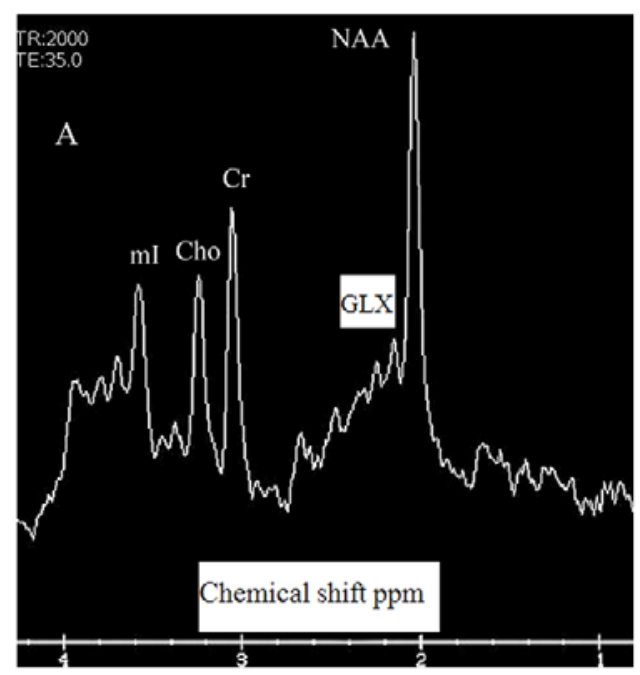

Figure 2. Example of spectrum in the same area with metabolite peaks.

NAA: N-acetyl-aspartate; Ch. Choline compounds; Cr creatine, mI: myo-inositol. GLX: glutamate.

There is no consensus so far regarding the most appropriate Echo Times (TE) in MRS. A short TE (20-40 ms) allows us to increase the signal/noise ratio and to visualize most metabolite peaks, although it presents one inconvenience in that there 
is of some degree of overlapping in the peaks. Intermediate TE (135-144 ms) inverts the lactate peak to better distinguish it from the lipids peak. Long TEs (270-288 ms) give a worse signal/noise ratio, but allow better visualization of some peaks (NAA, Choline, and Creatine), because they suppress the signal of others (myo-inositol, alanine, glutamateglutamine) ${ }^{[13,14]}$.

\section{MRS studies in Alzheimer's disease and MCI}

There are cross-sectional studies dealing with MRS in AD. A study including 206 normal elderly subjects and 121 patients with Alzheimer's disease demonstrated a decrease in the NAA/Cr ratios as well as increased $\mathrm{mI} / \mathrm{Cr}$ and $\mathrm{Ch} / \mathrm{Cr}$ ratios in the left posterior cingulate gyrus in AD patients as compared with controls ${ }^{[15]}$. Alterations have been found in many cortical and subcortical areas; these have mainly been found in the medial temporal lobe ${ }^{[16,17]}$, but also in other cortical areas such as the frontal cortex ${ }^{[18,19]}$, the parietal ${ }^{[20,21]}$, and the occipital cortex ${ }^{[22-254]}$. Some studies suggest a continuum between normal aging, MCI and AD with regard to the values of $\mathrm{N}$-acetyl aspartate in the brain ${ }^{[25,26]}$. By means of RS of the posterior cingulate cortex, the NAA/Cr ratio discriminated MCI from AD patients at $67 \%$ sensitivity and $80 \%$ specificity ${ }^{[26]}$.

Longitudinal studies also confirm the utility of MRS as biomarker. In a cohort of $53 \mathrm{MCI}$ patients we found good predictive values with MRS with the voxel positioned in the medial left occipital lobe but not neither in the midparietal cortex nor in the hippocampus ${ }^{[27]}$. Theoretically the values in the hippocampus should have been better but this area is subject to artifacts due to the proximity of air and osseous structures. We repeated a similar study with a larger cohort of 71 MCI patients but on this occasion put the voxel in the left medial occipital lobe and in the bilateral posteromedial parietal cortex that included the posterior cingulate gyrus and inferior precuneus. The predictive values were better in the posteromedial parietal cortex (74\% sensitivity; $83 \%$ specificity) but both areas were useful as target for prediction ${ }^{[28]}$. Other longitudinal studies with shorter follow-up periods yielded also good predictive values in the posteromedial parietal cortex ${ }^{[29]}$, left paratrigonal area ${ }^{[30]}$, and hippocampus ${ }^{[31]}$.

Additional longitudinal studies showed valuable results with MRS. In a large cohort of $151 \mathrm{MCI}$ patients (most being of amnestic type) followed-up for 3 years, MRS was individually predictive of conversion to dementia but the accuracy of prediction improved when MRS was used in combination with hippocampal volumetry and the presence of cortical infarctions ${ }^{[32]}$. Longitudinal studies with repeated measurements are also of interest by demonstrating that NAA levels decrease in parallel with cognitive deterioration. In a small cohort of MCI (15) patients and controls (12) the ratios of $\mathrm{NAA} / \mathrm{Cr}$ in the parietal lobe decreased longitudinally more in patients who converted to dementia than in nonconverters ${ }^{[33]}$. On the basis of another cohort composed of $16 \mathrm{MCI}$ patients who converted to dementia and other 16 who did not, it was also observed that NAA levels decreased significantly more in converters than in non-converters ${ }^{\text {[34] }}$.

The value of proton MRS as a biomarker was assessed ante-mortem in a single study with 54 patients ranging from low to high likelihood of having AD and who underwent autopsy. Decreases in NAA/Cr and increases in $\mathrm{mI} / \mathrm{Cr}$ ratios correlated with higher Braak neuropathological stages in the posterior bilateral cingulate gyrus ${ }^{[35]}$. Furthermore, the value of MRS as biomarker has been confirmed with the fact that changes in metabolite ratios are detected years before the clinical onset of $\mathrm{AD}$ in subjects carrying mutations in presenilins ${ }^{[36]}$ or protein tau ${ }^{[37]}$ genes.

In comparison to other MRI techniques such as Diffusion and Perfusion MRI this technique is more objective and has proven more reliable ${ }^{[38]}$.

Diffusion weighted imaging (DWI) is a structural method that assesses the microscopic translational movement of molecules via thermally driven random, so called Brownian motion of water molecules. The increased diffusion in brains with $\mathrm{AD}$ has been attributed to the decrease of neurons, axons and dendrites, leading to expansion of extracellular space 
and spreading the water more quickly. However the value of diffusion MRI has been questioned as sensitivity is low to distinguish $\mathrm{AD}$ patients from controls using apparent diffusion coefficients in the hippocampus.

The available studies of Diffusion Tensor Imaging in mild AD are difficult to compare because a consensus on the best acquisition protocols, tensor metrics, and statistical analytical techniques has not yet emerged. Furthermore the pathophysiology of Diffusion Tensor Imaging alterations in AD has not been well defined.

Perfusion-MR is a functional technique that allows measurement of many hemodynamic parameters including relative cerebral blood volume, cerebral blood flow and mean transit time (MTT). Numerous techniques have been proposed in last years to measure various perfusion related parameters in the brain. Two approaches have proven successful: injection of paramagnetic contrast agents for measuring cerebral blood volumes (CBV) and arterial spin labeling (ASL) for measuring cerebral blood flow (CBF). ASL-MRI offers several advantages over PET and SPECT: a) it is free of exposure to ionizing radiation, intravenous contrast agents, and radioactive isotopes; b) it can be rapidly repeated because labeled water is cleared after a few seconds. An additional advantage is that perfusion and structural images can be acquired at the same imaging session. This technique is currently under investigation to try to improve the signal/noise ratio, and when achieved, it will probably be very effective and completely non-invasive ${ }^{[38]}$.

\section{MRS to track progression of AD}

As it was mentioned above the main findings of MRS in the brain of AD are decreased NAA levels and ratios and increased $\mathrm{mI}$. A previous longitudinal study showed that NAA/Cr ratios declined significantly in MCI and AD patients, and it occurred in parallel with the progression of $\mathrm{AD}$ in the posterior cingulate gyrus despite $75 \%$ of $\mathrm{AD}$ patients took cholinesterase inhibitors. The $\mathrm{mI} / \mathrm{Cr}$ ratios tended to increase but it was not significant. Surprisingly, the $\mathrm{Ch} / \mathrm{Cr}$ ratios decreased in stable MCI patients compared with controls and MCI patients who convert to AD.39 Several published trials measured the effect of drugs on AD progression with MRS ${ }^{[40-47]}$. In table 1 are presented the main characteristics and outcomes of these trials. As we can see in general the drugs produced small changes in metabolite levels and ratios which correlated with the modest clinical or no effect of the drugs on AD progression. In a small trial with xanomeline, a muscarinic agonist, the cytosolic choline decreased in parietal cortex in comparison with controls.39 The same authors tried to confirm the results in an additional trial but only 8 patients in total completed the trial. $41 \mathrm{~A}$ randomized trial included 67 patients who were treated with either donepezil or placebo for one year. The NAA levels elevated transiently in the donepezil group at week 12 and 18 but the differences were not significant at endpoint, and cognitive improvement correlated with NAA elevations in the cortex. Conversely, in the placebo group the NAA concentration tended to remain near baseline values or to decrease modestly ${ }^{[42]}$. In another controlled trial Rivastigmine tended to increase the NAA levels after 4 months in 24 AD patients in several areas of the brain with little improvement on cognition but without statistical significance in both variables, whereas in the comparison untreated group tended to decrease ${ }^{[43]}$. A small and uncontrolled trial with 17 patients treated with donepezil for 4 months showed a correlation between cognitive function and NAA level changes in the parietal lobe.44 In another study with 15 AD patients treated with donepezil the NAA levels in the right hippocampus decreased after 4 months with no changes in cognitive function ${ }^{[45]}$. A randomized trial comparing donepezil with Memantine for 6 months showed no significant differences in clinical scales and metabolite levels. However in the whole sample of 63 patients the changes in the ADAS-cog correlated with the changes in the posteromedial parietal cortex ${ }^{[46]}$. In a small double blind placebo controlled trial with Memantine the lack of changes in metabolite ratios correlated with the lack of clinical effect in AD compared with controls ${ }^{[47]}$.

In two of these trials it could be also concluded that the sample size required in a trial of AD patients to see relevant MRS changes was lower than the sample required if it is only based on the equivalent changes in clinical scales such as ADAS-cog ${ }^{[43,46]}$. 
Table 1. List of trials using MRS to monitor progression and response to treatment in AD.

\begin{tabular}{|c|c|c|c|}
\hline AUTHOR & TYPE OF TRIAL & DRUG and follow-up & OUTCOMES \\
\hline Satlin A et al 1997 & Placebo Controlled. $\mathrm{N}=20$ & Xanomelina for 6 months & Decreased cytosolic choline \\
\hline Krishnan 2003 & RPCT. $\mathrm{N}=67$ & Donepezil for one year & $\begin{array}{l}\text { Transient increased NAA/Cr in several } \\
\text { areas }\end{array}$ \\
\hline Modrego 2006 & Controlled trial. $\mathrm{N}=34$ & Rivastigmine for 16 weeks & $\begin{array}{l}\text { Increased NAA/Cr in anterior cingulated } \\
\text { gyrus }\end{array}$ \\
\hline Jessen 2006 & Open trial. $\mathrm{N}=17$ & Donepezil for 3 months & $\begin{array}{l}\text { Correlation clinical changes-NAA levels } \\
\text { change in parietal lobe }\end{array}$ \\
\hline Modrego 2010 & $\begin{array}{l}\text { Randomised comparative } \\
\text { trial. } \mathrm{N}=63\end{array}$ & $\begin{array}{l}\text { Donepezil or Memantine } \\
\text { for } 6 \text { months }\end{array}$ & $\begin{array}{l}\text { No great differences in metabolite } \\
\text { changes. Correlation clinical } \\
\text { changes-MRS changes }\end{array}$ \\
\hline Bartha 2008 & Open. $\mathrm{N}=15$ & Donepezil for 4 months & NAA levels decreased in the hippocampus \\
\hline Ashford 2011 & DBPC trial. $\mathrm{N}=10$ & $\begin{array}{l}\text { Memantine or placebo for } \\
54 \text { weeks }\end{array}$ & $\begin{array}{l}\text { No significant changes. Correlation } \\
\text { clinical canges-NAA/Cr changes }\end{array}$ \\
\hline
\end{tabular}

Note. RPCT: randomized placebo-controlled trial

A longitudinal study including $42 \mathrm{AD}$ patients and 22 controls that underwent six Magnetic Resonance Spectroscopy studies within an elapse of time of 2 years showed that there is a progressive decline in the NAA/Cr ratios regardless of treatment with cholinesterase inhibitors ${ }^{[48]}$.

Glutamate is another neurotransmitter studied with MRS. Increased glutamatergic excitotoxicity has been reported in AD but several cross-sectional reports showed decreased levels of glutamate in $\mathrm{AD}$ in comparison with controls ${ }^{\text {[49-52] }}$. In a small open trial, galantamine treatment for 4 months tended to elevate glutamate levels in the hippocampus ${ }^{[53]}$.

\section{Strengths and weaknesses of MRS to detect early AD}

This technique has some advantages in comparison with other neuroradiological techniques. It is objective as metabolite measurements are made in an automated manner whereas medial temporal lobe structures volumetry is subject to inter-subject variability and artifacts ${ }^{[54]}$. In terms of reproducibility MRS reached a high intra-class correlation coefficient of metabolite levels, especially in the posteromedial parietal cortex, between two repeated measurements ${ }^{[55]}$. Furthermore the predictive values are similar to those obtained with volumetry in the two largest series ever studied in MCI: one of them included 389 patients) ${ }^{[56]}$ in which sensitivity of whole brain volumetry was $75 \%$ and specificity was $68.8 \%$; the other one ${ }^{[57]}$ included 139 MCI patients who underwent hippocampal plus entorhinal volumetry, with sensitivity of $66.7 \%$ and specificity of $80 \%$.

Of course there are some limitations to bear in mind with regard to MRS. Putting the voxel in the CSF or air may result in false metabolite measurements. Reliable values require the correction for atrophy and the presence of CSF with the appropriate and not always affordable software. Alternatively the use of the ratios to creatine can lessen this caveat. The homogeneity of the magnetic field should be checked frequently to avoid bad quality spectra. The voxel size should be appropriate for the structure examined. In this sense a voxel of $2 \mathrm{~cm} \times 2 \mathrm{~cm} \times 2 \mathrm{~cm}$ is too large for exploring the hippocampus but smaller areas can now be explored with modern scanners. To overcome these limitations the high-field 3T clinical scanners seem to be promising as they can discriminate between normality, MCI and AD in the hippocampus with small size voxels, although the number of patients was low ${ }^{[58,59]}$. A detailed presentation of $1 \mathrm{H}$ MRS methodology developments and subsequent quantitation has been published ${ }^{[60,61]}$.

So far MRS has proven useful in MCI and AD but we do not have enough studies to advocate use in presymptomatic stages of AD. For this purpose other biomarkers are better known (CSF A $\beta 42$ and amyloid PET) ${ }^{[62]}$. What we call 
amnestic MCI may be considered as a prodromos of $\mathrm{AD}$ or a condition at high risk of conversion to $\mathrm{AD}$ because eventually most patients convert to dementia. There are two reports in which over time $100 \%$ of patients had converted to dementia when followed for 10 years ${ }^{[6,7]}$. In a retrospective study we saw that $\mathrm{AD}$ patients preceded by MCI for longer than one year periods had lower NAA levels in several areas of the brain and more depressive symptoms that those not preceded by evident prodromal MCI ${ }^{[63]}$. Therefore the studies conducted in amnestic MCI are biased in the sense of an excess of conversion rates and we should use the expression "early conversion to $\mathrm{AD}$ " rather than conversion to $\mathrm{AD}$.

In conclusion, MRS is a useful tool in AD not only for early detection but also for tracking progression of the disease with and without pharmacological treatment. Studies comparing this technique with other biomarkers are warranted.

\section{References}

[1] Petersen RC, Smith GE, Waring SC, Ivnik RJ, Tangalos EG, Kokmen E. Mild Cognitive Impairment. Clinical characterization and outcome. Arch Neurol. 1999; 56: 303-308. PMid:10190820 http://dx.doi.org/10.1001/archneur.56.3.303

[2] Lopez OL, Becker JT, Jagust W, et al. Neuropsychological characteristics of mild cognitive impairment subgroups. J Neurol Neurosurg Psychiatry. 2006; 77: 159-165. PMid:16103044 http://dx.doi.org/10.1136/jnnp.2004.045567

[3] Johnson KA, Jones K, Holman BL. Preclinical prediction of of Alzheimer's disease using SPECT. Neurology. 1998 ; 50 : $1563-1572$. PMid:9633695 http://dx.doi.org/10.1212/WNL.50.6.1563

[4] Bennet DA, Wilson RS, Schneider JA, et al. Natural history of mild cognitive impairment in older persons. Neurology. 2002; 59: 198-205. http://dx.doi.org/10.1212/WNL.59.2.198

[5] McKelvey R, Bergman H, Stern J. Lack of prognostic significance of SPECT abnormalities in elderly subjects with a mild memory loss. Can J Neurol Sci. 1999; 26: 23-28. PMid:10068803

[6] Krasuki JS, Alexander, Horwitz B, et al. Volumes of medial temporal lobe structures in patients with Alzheimer's disease and mild cognitive impairment (and in healthy controls). Biol Psychiatry. 1998; 43: 60-68. http://dx.doi.org/10.1016/S0006-3223(97)00013-9

[7] Morris JC, Storandt M, Miller JP, et al. Mild Cognitive Impairment represents early-stage Alzheimer's disease. Arch Neurol. 2001; 58: 397-405. PMid:11255443 http://dx.doi.org/10.1001/archneur.58.3.397

[8] Albert MS, DeKosky ST, Dickson D, Dubois B, Feldman HH, Fox NC, Gamst A, Holtzman DM, Jagust WJ, Petersen RC, Snyder PJ, Carrillo MC, Thies B, Phelps CH. The diagnosis of mild cognitive impairment due to Alzheimer's disease: Recommendations of the National Institute on aging-Alzheimer's Association workgroups on diagnostic guidelines for Alzheimer's disease. Alzheimers Dement. 2011; 7: 270-279. PMid:21514249 http://dx.doi.org/10.1016/j.jalz.2011.03.008

[9] Fayed N, Olmos S, Morales H, Modrego PJ. Physical basis of Magnetic Resonance Spectroscopy and its application to Central Nervous System diseases. Am J Appl Sci. 2006; 3: 1836-1845. http://dx.doi.org/10.3844/ajassp.2006.1836.1845

[10] Hsu YY, Chang C, Chang CN, Chu NS, Lim KE, Hsu JC. Proton MR spectroscopy in patients with complex partial seizures: single-voxel spectroscopy versus chemical-shift imaging. AJNR Am J Neuroradiol. 1999; 20(4): 643-51. PMid:10319976

[11] Hsu YY, Chen MC, Lim KE, Chang C. Reproducibility of hippocampal single-voxel proton MR spectroscopy and chemical shift imaging. AJR Am J Roentgenol .2000; 176(2): 529-36.

[12] Maheshwari S, Fatterpeaker G, Castillo M, Mukherji SK. Proton MR spectroscopy of the brain. Semin Ultrasound CT MR. 2000; 21(6): 434-451. http://dx.doi.org/10.1016/S0887-2171(00)90036-2

[13] Bonavita S, Di Salle F, Tedeschi G, Proton MRS in neurological disorders. Eur J Radiol. 1999; 30: 125-131. http://dx.doi.org/10.1016/S0720-048X(99)00051-0

[14] Burlina A, Aureli T, Bracco F, Conti F, Battistin L. MR spectroscopy: a powerful tool for investigating brain function and neurological diseases. Neurochem Res. 2000; 25: 1365-1372. PMid:11059807 http://dx.doi.org/10.1023/A:1007660632520

[15] Kantarci K, Petersen RC, Boeve BF, et al. 1H MR spectroscopy in common dementias. Neurology. 2004; 63: 1393-1398. PMid:15505154 http://dx.doi.org/10.1212/01.WNL.0000141849.21256.AC

[16] Kantarci K, Jack CR, Xu YC, et al. Regional metabolic patterns in mild cognitive impairment and Alzheimer's disease. Neurology. 2000; 55: 210-217. PMid:10908893 http://dx.doi.org/10.1212/WNL.55.2.210

[17] Jessen F, Block W , Träber F, et al. Proton MR spectroscopy detects a relative decrease on N-acetylaspartate in the medial temporal lobe of patients with AD. Neurology. 2000; 55: 684-688. PMid:10980734 http://dx.doi.org/10.1212/WNL.55.5.684

[18] Christiansen P, Schlosser A, Henriksen O. Reduced N-acetylaspartate content in the frontal part of the brain in patients with probable Alzheimer's disease. Magn Reson Imaging. 1995; 13: 457-462. http://dx.doi.org/10.1016/0730-725X(94)00113-H

[19] Schuff N, Amend DL, Meyerhoff DJ, Tanabe JL, Norman D, Fein G, Weiner MW. Alzheimer disease: quantitative H-1 MR spectroscopic imaging of frontoparietal brain. Radiology. 1998; 207: 91-102. PMid:9530304 
[20] Schuff N, Capizzano A, Du AT, Amend DL, O’Neil J, Norman D, Kramer J, Jagust W, Miller B, Wolkowitz OM, Yaffe K, Weiner MW. Selective reduction of N-acetylaspartate in medial temporal and parietal lobes in AD. Neurology. 2002; 58: 928-935. PMid:11914410 http://dx.doi.org/10.1212/WNL.58.6.928

[21] MacKay S, Meyerhoff DJ, Constans JM, Norman D, Fein G, Weiner MW. Regional gray and white matter metabolic differences in subjects with $\mathrm{AD}$, with subcortical ischemic vascular dementia, and elderly controls with H Magnetic Resonance Spectroscopy Imaging. Arch Neurol. 1996; 53: 167-174. PMid:8639067 http://dx.doi.org/10.1001/archneur.1996.00550020079018

[22] Miller BL, Moats RA, Shonk T, Earnst E, Wooley S, Ross BD. Alzheimer's disease: depiction of increased cerebral myoinositol with proton MR spectroscopy. Radiology. 1993; 187:433-437. PMid:8475286

[23] Shonk TK, Moats RA, Gifford P, Michaelis T, Mandigo JC, Izumi J, Ross BD. Probable Alzheimer Disease: diagnosis with Proton MR Spectroscopy. Radiology. 1995; 195: 65-72. PMid:7892497

[24] Rai GS, McConnel JR, Waldman A, Grant D, Chaudhry M. Brain proton spectroscopy in dementia: an aid to clinical diagnosis. Lancet. 1999; 353: 1063-1064. http://dx.doi.org/10.1016/S0140-6736(98)03759-3

[25] Parnetti L, Lowenthal DT, Presciutti O, et al. 1 H-MRS, MRI-based hippocampal volumetry, and 99mTc-HMPAO-SPECT in normal aging, age-associated memory impairment, and probable Alzheimer's disease. J Am Geriatr Soc. 1996; 44: 133-138. PMid:8576501

[26] Kantarci K, Xu YC, Shiung MM, et al. Comparative diagnostic utility of different MR modalities in Mild Cognitive Impairment and Alzheimer's disease. Dement Geriatr Cogn Disord. 2002; 14: 198-207. PMid:12411762 http://dx.doi.org/10.1159/000066021

[27] Modrego PJ, Fayed N, Pina MA. Conversion from mild cognitive impairment to probable Alzheimer's disease predicted by brain Magnetic Resonance Spectroscopy. Am J Psychiatry. 2005; 162: 667-675. PMid:15800137 http://dx.doi.org/10.1176/appi.ajp.162.4.667

[28] Modrego PJ, Fayed N, Sarasa M. Magnetic Resonance Spectroscopy in the prediction of early conversion from amnestic Mild Cognitive Impairment to dementia. BMJ Open 2011; 1e: 000007. PMid:22021723 http://dx.doi.org/10.1136/bmjopen-2010-000007

[29] Fayed N, Dávila J, Oliveros A, Castillo J, Medrano JJ. Utility of different MR modalities in mild cognitive impairment and its use as a predictor of conversion to probable dementia. Acad Radiol. 2008; 15:1089-1098. PMid:18692749 http://dx.doi.org/10.1016/j.acra.2008.04.008

[30] Metastasio A, Rinaldi P, Tarducci R, et al. Conversión of MCI to dementia: Role of proton magnetic resonance spectroscopy. Neurobiol Aging. 2005; 27: 926-932. PMid:15936850 http://dx.doi.org/10.1016/j.neurobiolaging.2005.05.002

[31] Targosz-GajniakM, Siuda J, Wicher M, Bujak M, Opala G. Magnetic Resonance Spectroscopy as a predictor of conversion to dementia in mild cognitive impairment. Eur J Neurol. 2011; 18 (2): 350 (Abstract).

[32] Kantarci K, Weigand SD, Przybelski SA, et al. Risk of dementia in MCI. Combined effect of cerebrovascular disease, volumetric MRI, and H MRS. Neurology. 2009; 72: 1519-1525. PMid:19398707 http://dx.doi.org/10.1212/WNL.0b013e3181a2e864

[33] Pilatus U, Lais C, Rochmont Adu M, et al. Conversion to dementia in mild cognitive impairment is associated with decline of $\mathrm{N}$-acetylaspartate and creatine as revealed by magnetic resonance spectroscopy. Psychiatry Res. 2009; 173: 1-7. PMid:19427767 http://dx.doi.org/10.1016/j.pscychresns.2008.07.015

[34] Modrego PJ, Fayed N. Longitudinal MRS in mild cognitive impairment. Am J Alzheimers Dis Other Demen. 2011; $26: 631-636$. PMid:22323830 http://dx.doi.org/10.1177/1533317511433809

[35] Kantarci K, Knopman DS, Dickson DW, et al. Alzheimer disease: Postmortem neuropathologic correlates of antemortem 1-H MR Spectroscopy metabolite measurements. Radiology. 2008; 248: 210-220. PMid:18566174 http://dx.doi.org/10.1148/radiol.2481071590

[36] Godbolt AK, Waldman AD, MacManus DG, Schott JM, Frost C, Cipolotti L, et al. MRS shows abnormalities before symptoms in familial Alzheimer disease. Neurology. 2006; 66:718-722. PMid:16534109 http://dx.doi.org/10.1212/01.wnl.0000201237.05869.df

[37] Kantarci K, Boeve BF, Wszolek Z, et al. MRS in presymptomatic MAPT mutation carriers. Neurology. 2010: 75: 771-778. PMid:20805522 http://dx.doi.org/10.1212/WNL.0b013e3181f073c7

[38] Fayed N, Modrego PJ, Rojas-Salinas G, Gazulla J. Magnetic Resonance Imaging based Clinical Research in Alzheimer's disease. J Alzheimer Dis. 2012; 30: 1-14 (review).

[39] Kantarci K, Weigand SD, Petersen RC, et al. Longitudinal H MRS changes in mild cognitive impairment and Alzheimer's disease. Neurobiol Aging. 2007; 28: 1330-1339. PMid:16860440 http://dx.doi.org/10.1016/j.neurobiolaging.2006.06.018

[40] Satlin A, Bodick N, Offen WW, Renshaw PF. Brain proton magnetic resonance spectroscopy (1H-MRS) in Alzheimer's disease: changes after treatment with xanomeline, an M1 selective cholinergic agonist. Am J Psychiatry. 1997; 154:1459-1461. PMid:9326834

[41] Frederick B, Satlin A, Wald LL, Hennen J, Bodick N, Renshaw PF. Brain proton magnetic resonance spectroscopy in Alzheimer disease: changes after treatment with xanomeline. Am J Geriatr Psychiatry. 2002; 10:81-88. PMid:11790638 http://dx.doi.org/10.1176/appi.ajgp.10.1.81

[42] Krishnan RR, Charles HC, Doraiswamy PM (2003), et al. Randomized, placebo-controlled trial of the effects of donepezil on neuronal markers and hippocampal volumes in Alzheimer disease. Am J Psychiatry. 2003; 160: 2003-2011. PMid:14594748 http://dx.doi.org/10.1176/appi.ajp.160.11.2003

[43] Modrego PJ, Pina MA, Fayed N, Díaz M. Changes in metabolite ratios after treatment with rivastigmine in Alzheimer's disease: a nonrandomized controlled trial with magnetic resonance spectroscopy. CNS Drugs. 2006; 20: 867-87. PMid:16999455 http://dx.doi.org/10.2165/00023210-200620100-00006 
[44] Jessen F, Traeber F, Freymann K, Maier W, Schild HH, Block W. Treatment monitoring and response prediction with proton MR spectroscopy in AD. Neurology. 2006; 67: 528-530. PMid:16894124 http://dx.doi.org/10.1212/01.wnl.0000228218.68451.31

[45] Bartha R, Smith M, Rupsingh R, Rylett J, Wells JL, Borrie MJ. High field H MRS of the hippocampus after donepezil treatment in Alzheimer disease. Prog Neuropsychopharmacol Biol Psychiatry. 2008; 32; 786-793. PMid:18252268 http://dx.doi.org/10.1016/j.pnpbp.2007.12.011

[46] Modrego PJ, Fayed N, Errea JM, Rios C, Pina MA, Sarasa M. Memantine versus donepezil in mild to moderate Alzheimer's disease: a randomized trial with magnetic resonance spectroscopy. Eur J Neurol. 2010; 17:405-412. PMid:19874395 http://dx.doi.org/10.1111/j.1468-1331.2009.02816.x

[47] Ashford JW, Adamson M, Beale T, et al. MR spectroscopy for assessment of memantine treatment in mild to moderate Alzheimer dementia. J Alzheimers Dis. 2011; 26: 331-336. PMid:21971472

[48] Schott JM, Frost C, Macmanus DG, Ibrahim F, Waldman AD, Fox ND. Short echo time proton magnetic resonance spectroscopy in Alzheimer's disease: a longitudinal multiple time point study. Brain. 2010; 133: 3315-22. PMid:20739347 http://dx.doi.org/10.1093/brain/awq208

[49] Antuono PG, Jones JL, Wang Y, Li SJ. Decreased glutamate + glutamine in Alzheimer's disease detected in vivo with (1) H-MRS at 0.5 T. Neurology. 2002; 56: 737-42. http://dx.doi.org/10.1212/WNL.56.6.737

[50] Hattori N, Abe K, Sakoda S, Sawada T. Proton MR spectroscopic study at 3 Tesla on glutamate/glutamine in Alzheimer's disease. Neuroreport. 2002; 13: 183-186. PMid:11924885 http://dx.doi.org/10.1097/00001756-200201210-00041

[51] Rupsingh R, Borrie M, Smith M, Wells JL, Bartha R. Reduced hippocampal glutamate in Alzheimer disease. Neurobiology of Aging. 2009; 32(5): 802-10. PMid:19501936 http://dx.doi.org/10.1016/j.neurobiolaging.2009.05.002

[52] Fayed N, Modrego PJ, Rojas-Salinas G, Aguilar K. Glutamate is decreased in Alzheimer's disease. A magnetic resonance spectroscopy study. Am J Alzheimers Dis Other Demen. 2011; 26: 450-456. PMid:21921084 http://dx.doi.org/10.1177/1533317511421780

[53] Penner J, Rupsingh R, Smith M, Wells JL, Borrie MJ, Bartha R. Increased glutamate in the hippocampus after galantamine treatment for Alzheimer Disease. Prog Neuropsychopharmacol Biol Psychiatry. 2010; 34: 104-110. PMid:19833161 http://dx.doi.org/10.1016/j.pnpbp.2009.10.007

[54] Mega MS. The entorhinal cortex in Alzheimer's disease. J Neurol Neurosurg Psychiatry. 2001; 71: 43 1-432.

[55] Fayed N, Modrego PJ, Medrano J. Comparative test-retest reliability of metabolite values assessed with Magnetic Resonance Spectroscopy of the brain. The LCModel versus the manufacturer software. Neurol Res. 2009; 31: 472-477. PMid:19215666 http://dx.doi.org/10.1179/174313209X395481

[56] Nho K, Shen L, Risacher SL, West JD, Foroud T, Jack CR, Weiner MW, Saykin AJ. Automatic prediction of conversion from mild cognitive imapirment to probable Alzheimer's disease using structural magnetic resonance imaging. AMIA Annu Symp Proc. 2010; 13: $542-546$

[57] Devanand DP, Pradhaban G, Liu X, Khandji A, De Santi S, Segal S, Rusinek H, Pelton GH, Honig LS, Mayeux R, Stern Y, Tabert MH, de Leon MJ. Hippocampal and entorhinal atrophy in mild cognitive impairment: prediction of Alzheimer disease. Neurology. 2007; 68: 828-836. PMid:17353470 http://dx.doi.org/10.1212/01.wnl.0000256697.20968.d7

[58] Wang Z, Zhao C, Yu L, Zhou W, Li K. Regional metabolic changes in the hippocampus and posterior cingulated area detected with 3-Tesla Magnetic resonance spectroscopy in patients with mild cognitive impairment and Alzheimer's disease. Acta Radiol. 2009; 50: 312-319. PMid:19235582 http://dx.doi.org/10.1080/02841850802709219

[59] Caserta MT, Ragin A, Hermida AP, John Ahrens R, Wise L. Single voxel MR spectroscopy at 3T in a memory disorders clinic: early right hippocampal NAA/Cr loss in mildly impaired subjects. Psychiatry Res. 2008; 164: 154-159. PMid:18930637 http://dx.doi.org/10.1016/j.pscychresns.2008.04.002

[60] Mandal PK. Magnetic Resonance Spectroscopy (MRS) and its application in Alzheimer's Disease. Concepts in Magnetic Resonance Part A. 2007; 30: 40-65. http://dx.doi.org/10.1002/cmr.a.20072

[61] Mandal PK. In vivo proton magnetic resonance spectroscopic signal processing for the absolute quantitation of brain metabolites. Eur J Radiol 2011. Ahead of print.

[62] Petersen RC, Roberts RO, Knopman DS, Boeve BF, Geda YE, Ivnik RJ, Smith GE, Jack CR. Mild cognitive impairment. Ten years later. Arch Neurol. 2010; 66: 1447-1455. PMid:20008648 http://dx.doi.org/10.1001/archneurol.2009.266

[63] Modrego PJ, Fayed N, Olmos S. Clinical and radiological differences in Alzheimer's disease with and without a history of mild cognitive impairment. Neuroradiology J. 2010; 23: 659-664. 